Facilitating ethical reflection among scientists using the ethical matrix

Jensen, Karsten Klint; Forsberg, Ellen-Marie; Gamborg, Christian; Millar, Kate; Sandøe, Peter

Published in:

Science and Engineering Ethics

DOI:

10.1007/s11948-010-9218-2

Publication date:

2011

Document version

Peer reviewed version

Citation for published version (APA):

Jensen, K. K., Forsberg, E-M., Gamborg, C., Millar, K., \& Sandøe, P. (2011). Facilitating ethical reflection among scientists using the ethical matrix. Science and Engineering Ethics, 17(3), 425-445.

https://doi.org/10.1007/s11948-010-9218-2 


\title{
Facilitating Ethical Reflection Among Scientists Using the Ethical Matrix ${ }^{1}$
}

\author{
K. K. Jensen, E-M Forsberg, C. Gamborg, K. Millar, \& P. Sandøe* \\ Corresponding author, pes@sund.ku.dk
}

\section{Introduction}

Scientists, particularly in the biosciences, are challenged and encouraged to engage in ethical reflection regarding their research objectives and programmes. Both national and EU funders increasingly ask for an ethical review of project proposals and the inclusion of activities within funded projects that encourage ethical reflection. These project-based processes often form an integrated part of large bioscience projects (for example, as funded by the European Commission through the $6^{\text {th }}$ and $7^{\text {th }}$ Research Framework Programmes). There are a number of drivers for these processes and requirements, including the view that researchers may be seen as partly responsible for modern biotechnology developments and as such should be aware of the ethical questions raised by their research as well as being transparent about their activities. Hence, they should be involved in identifying ethical aspects of new technologies, including benefits and risks, as well as highlighting possible wider regulatory needs.

However, research findings have indicated that scientists are likely to have an outlook which is different to that of lay people in important ways. For instance, risk perception studies indicate that experts perceive risks differently from non-expert publics or 'lay' people (e.g. Slovic 2000). Sociological studies also reveal that these lay publics can possess knowledge or perspectives that scientists may overlook or ignore (e.g. Wynne 1996). Finally, whereas scientists typically have the task of assessing risks for 'others', they often overlook that non-scientists, lay people, can have other values which extend beyond avoiding risks. For instance, looking at the debate surrounding the use of GM foods, it has become evident that apart from risk, lay publics are concerned with issues such as the size of potential benefits and their distribution; concerns about the concentration of economic power in the food sector; and the "unnaturalness" of GM products (e.g. Lassen et al. 2002). Hence, these groups may often have a different value agenda from that of most scientific experts.

These findings appear to have led many to the inference that if ethical reflection was to take place only among a relatively a homogenous group of scientists such discussions might be limited due to the participants' insufficient awareness of the views and values of external stakeholders. A consequence of this limitation would require that, in order to perform a reliable ethical reflection exercise, scientists need to engage in dialogue with other stakeholders, in particular with representatives of user groups and publics

\footnotetext{
${ }^{1}$ The reference of the printed version is:

Jensen, K. K., Forsberg, E-M., Gamborg, C., Millar, K., \& Sandøe, P. (2011). Facilitating ethical reflection among scientists using the ethical matrix. Science and Engineering Ethics, 17(3), 425-445.

The definitive version is available at https://doi.org/10.1007/s11948-010-9218-2
} 
This is a post-print version of an article published in Science and Engineering Ethics by Springer

For more articles on animal ethics, see www.animalethics.net

potentially affected by the innovation in question. As a result, many techniques for running ethical reflection processes build on this multi-stakeholder premise, e.g. consensus conferences, stakeholder audits, etc.

However, the observations and reflections in the field of applied ethics presented here appear to indicate that this inference may not hold true in all circumstances. This paper describes an attempt to conduct an ethical reflection exercise with a group of scientists on the issues raised by their research activities without the involvement of external stakeholders. It reports on the outcomes of four workshops held with scientists involved in a genomics network, the EADGENE Network of Excellence, which aimed to encourage ethical reflection and increase ethical capacity within the Network. Consideration of the provisional findings of this process leads to a discussion of the whether it is possible to have valuable ethical reflection without actual representation of affected parties/stakeholders if a method, such as the ethical matrix, stimulates reflection beyond traditional value boundaries of the group.

EADGENE is an EU funded network that focuses on coordinating a genomics approach to the unraveling of host-pathogen interactions in animal production. This Network aims to provide the basic knowledge necessary for the development of new or improved therapeutics and vaccines, for diagnostics and the breeding of farm animals for increased disease resistance. Genomics of host-pathogen interactions holds the promise of improved disease control in animals, but bioscience research and the development of modern biotechnologies are known to give rise to value conflicts and controversies. Scientists working with animal disease genomics are faced with a number of ethical challenges, for example: How might this work impact on the welfare of research animals and future production animals? Are there any notable patenting and commercial ownership issues raised, and may these issues affect the objectivity of the results found?

In addition to the four workshops which explored ethical issues relating to the research conducted, the Network was given the opportunity to hold an additional (fifth) workshop which included a number of external stakeholders. In all the workshops a modified version of the Ethical Matrix method (Mepham et al, 2006) was used as the facilitation tool.

In addition to the five workshops, the analysis also draws on the outcomes of other activities that were used to engage EADGENE Network scientists in ethical reflection, activities which took place prior to the workshops. Before reporting on the outcomes of the workshops, this paper firstly describes the method used and concludes by discussing the significance of the workshop outcomes.

\section{Method}

In order to facilitate a process of ethical reflection, each of the workshops used a tool known as the Ethical Matrix (Mepham et al. 2006). This tool, first introduced by Ben Mepham of University of Nottingham, UK, was initially designed to facilitate ethical deliberations amongst those individuals who have particular scientific or policy knowledge, but who either have little or no formal training in the field of ethics. Since this initial application, it has been developed and applied in different ways (e.g. Forsberg 2007a; England and Millar, 2008). In its original form the ethical matrix applies a set of ethical principles to a number of selected interest groups (a generic matrix is shown in Figure 1); these groups are defined as the affected parties. The groups may represent different people, such as food producers or consumers, but equally they can represent other parties which may have ethical status but which are unable to voice their concerns, such as farm animals or wildlife. 
This is a post-print version of an article published in

Science and Engineering Ethics by Springer

For more articles on animal ethics, see www.animalethics.net

\begin{tabular}{|c|c|c|c|}
\hline \multicolumn{4}{|c|}{ (Translation of the ethical principles for the corresponding interest group) } \\
\hline & WELLBEING & AUTONOMY & FAIRNESS \\
\hline TREATED ANIMAL & $\begin{array}{l}\text { Animal } \\
\text { welfare }\end{array}$ & $\begin{array}{l}\text { Behavioural } \\
\text { Freedom }\end{array}$ & $\begin{array}{l}\text { Intrinsic } \\
\text { value }\end{array}$ \\
\hline PRODUCERS & $\begin{array}{l}\text { Satisfactory } \\
\text { income and } \\
\text { working conditions }\end{array}$ & $\begin{array}{l}\text { Managerial } \\
\text { freedom }\end{array}$ & $\begin{array}{l}\text { Equitable IPR conditions, } \\
\text { trading and market } \\
\text { systems }\end{array}$ \\
\hline $\begin{array}{l}\text { CONSUMERS } \\
\text { (including affected } \\
\text { citizens) }\end{array}$ & $\begin{array}{l}\text { Food safety and } \\
\text { quality of life }\end{array}$ & $\begin{array}{l}\text { Informed } \\
\text { democratic choice }\end{array}$ & $\begin{array}{l}\text { Affordability and } \\
\text { access } \\
\text { to food }\end{array}$ \\
\hline $\begin{array}{l}\text { ENVIRONMENT } \\
\text { (Biota) }\end{array}$ & $\begin{array}{l}\text { Conservation } \\
\text { and Protection }\end{array}$ & Biodiversity & Sustainability \\
\hline
\end{tabular}

Figure 1. Generic Ethical matrix

What are taken to be the relevant interest groups varies from case-to-case and the number of interest groups is not necessarily restricted to four. In the EADGENE Network a modified ethical matrix was used as a point of departure for the discussions in the workshops (see Figure 2). For the EADGENE matrix, 'scientists' are suggested as a stakeholder group because they do the research the impact of which is under consideration. Also, a distinction is made between 'animals in research' and 'production animals', because their interests are assumed to differ in the sense that the former are subjected to experiments and directly affected by the activities carried out by the scientists, whereas the latter largely are considered beneficiaries and are only indirectly affected. 
This is a post-print version of an article published in

Science and Engineering Ethics by Springer

For more articles on animal ethics, see www.animalethics.net

\begin{tabular}{|l|l|l|l|}
\hline & \multicolumn{3}{|c|}{ Respect for } \\
\hline Interest group & WELLBEING & AUTONOMY & JUSTICE \\
\hline PRODUCERS/INDUSTRY & & & \\
\hline CONSUMERS/CITIZENS & & & \\
\hline SCIENTISTS & & & \\
\hline ANIMALS IN RESEARCH & & & \\
\hline PRODUCTION ANIMALS & & & \\
\hline ENVIRONMENT & & & \\
\hline
\end{tabular}

Figure 2. The matrix used in the workshops

The aim of the Ethical Matrix method is to ensure that when assessing a technology or experiment, all relevant interest groups which may be affected are considered. This is achieved by assessing the impacts of the use of a technology by applying the three ethical principles (i.e. wellbeing, autonomy and justice) to each of the interest groups. When mapping ethical impacts and the issues raised for individual cells, it may be necessary to discuss or further elaborate on the interpretation of the principle as depicted in the generic matrix in order to more accurately reflect the particular issue at hand (Mepham et al. 2006). Hence, the principles and content of the cells may be further interpreted by the group using the matrix.

In order to flesh out the content of the cells, both factual and normative information is drawn on. Some of the underlying facts may be rather straightforward and unchallenged whereas other facts may be a source of substantial disagreement. Thus, the matrix also presents an opportunity to challenge the assessment of 'evidence' and therefore its use may help to highlight key controversies within a specific field that has relevance to the assessment of a new technology. When examining risk issues, it may be important to know more than the frequency and probabilities of the impacts, is may also be necessary to judge what is considered an acceptable risk (Kaiser, 2005). Thus the consideration of an individual cell is not exhausted by quantifiable consequences alone, but it is affected by the value attributed to each impact and the overall significance of the cell (Mepham et al., 2006). Moreover, there might be agreement on some factual issues but a difference in the weight or importance assigned to these facts, and in these cases the matrix may help to locate key conflicts or controversies concerning specific evaluative or value-based questions. 
This is a post-print version of an article published in Science and Engineering Ethics by Springer

For more articles on animal ethics, see www.animalethics.net

When the Ethical Matrix was first applied as a participatory tool, it was used with a multi-stakeholder group (Millar and Mepham, 2001). However, it may be argued that successful use of the method is dependent on the users being prepared to conscientiously 'put themselves in the shoes of others', (i.e. other stakeholders) rather than be reliant on the interventions of representatives of specific stakeholder groups as identified in the Ethical Matrix. For one thing, animals and the environment must necessarily be represented by humans and generally, users are not encouraged to argue from their own perspective, but rather to examine the interests of all affected parties. Originally the method was applied by a single individual in order to structure an ethical assessment (Mepham, 1996). Hence, in principle there appears to be nothing against using the Ethical Matrix in a modified form with participants from a single stakeholder group, even if the members of such a group are expected to hold relatively uniform views.

The ethical matrix was applied in the EADGENE workshops held in four different European locations between November 2007 and February 2008 (Roslin Institute, November 2007; University of Liege, December 2007; Wageningen University, January 2008; and INRA, Paris, February, 2008). The majority of the participants were scientists from universities or industry (representatives from the breeding industry participate in the Network). One or two individuals with a professional ethics background also participated.

Each workshop followed the same structure and timetable. At each event a different case emerging from research at the host institute was used to initiate discussion. However, this initial discussion of the case developed into a more general discussion of the issues raised by animal disease genomics research.

The objective of the workshops was twofold, to facilitate an exchange and analysis of viewpoints amongst the participants, and to more widely build capacity within the Network to engage in ethical discourse. It should be stressed that the aim was not to arrive at any kind of consensual judgment on the ethical acceptability of the case or genomic research per se, but to map and clarify ethically perspectives relevant for the group. In order to achieve this, the participants were divided into two groups, and they were asked to discuss and respond to the following four questions:

i. What are the ethical issues at stake in relation to both the case and to animal disease genomics?

ii. What ethical issues would you consider most significant?

iii. What are your main responsibilities with regard to these issues?

iv. How should these issues be dealt with?

Two workshop facilitators, one for each group, helped the participants work through these question, and the groups used the modified ethical matrix shown in Figure 2 to structure their discussion. When discussing the first question the matrix was 'filled in' using the groups own summary of their discussion (shorthand prompts were often used). This formed the basis for the group's further discussion of the following questions and presentation in workshop plenum.

An additional fifth workshop took place at the Roslin Institute (January 2009) with participants from the Network and selected external stakeholders who represented various agriculture and animal welfare nongovernmental organizations (NGOs). The structure of this workshop was the same as previous workshops, although some variation was inevitable. Thus a specific case was not used as the starting point for the dialogue (as was the case in the four other workshops). This design feature was chosen due to the mix of external stakeholders and the need to facilitate broad discussion within a multi-disciplinary group. 
This is a post-print version of an article published in Science and Engineering Ethics by Springer

For more articles on animal ethics, see www.animalethics.net

All the workshops were evaluated through feedback forms in terms of the participants' views of the process and the outcomes. Moreover, after the workshops, a qualitative evaluation was carried out by the authors where key themes and focal points within the discourse were identified. In particular this part of the analysis attempted to identify issues within the first four workshops such as: the representation of other stakeholders' interests; the scientific group's evaluation of the issues and whether these appear to deviate notably from some previously reported public concerns; a lack of reflection or criticism of research teams' roles and responsibilities, and other aspects that may suggest a narrow homogeneous dialogue; and finally, to identify whether there were notable differences between the four internal workshops and the fifth workshop with external participants.

\section{Outcome of the ethical matrix workshops}

In this section the outcomes first four workshops discussions are initially reviewed. This discussion is based on the 'filled in' matrices from the parallel group sessions and the authors' observations from the workshops. When discussing the matrices, they way in which the 'cells' were 'filled' should be noted. Each group structured its own discussion, however these discussions were not transcribed, it was a support activity for the participants themselves so that they could 'see' the path of their discussion. Each matrix represents a specific group's own summary of the discussion, set out in note form. Since the discussion and arguments underlying these 'statements' were not collected with the intent that they should represent data or be directly analyzed they should be interpreted with caution. Also, since the groups each followed their own structure and interpretation of the cells, comparison between each cell, e.g. cell to cell, is not straightforward here. Related issues may have been put in different cells by different groups. Even so, a few examples of 'filled in' matrices are included to highlight the reflective issues discussed in this paper, to highlight how the matrices were 'filled in', to highlight the flexibility of the Ethical Matrix and to give an indication of similarities and variations across groups and workshops. Some of the key issues are reviewed and commented on below.

Two examples of completed matrices are given in Figure 3 (Matrix A) and Figure $4 \mathrm{a}$ and $4 \mathrm{~b}$ (Matrix B). The matrix in Figure 3 took its departure from the discussion of research in a bovine medicine. The matrix in Figure 4a stems from discussion of breeding for more robust poultry. This table also shows how some groups made further distinctions among interest groups. Such variations represent group lead ownership of the method as demonstrated through the modification. In terms of reflection on overarching benefits, the participants in group A expected research to have economic impact for dairy producers. Similarly, group B expected enhanced productivity and income for egg producers. For the consumers, group A expect increased food security, but also mentions consumer concerns about animal experiments and risks from the drug under consideration. Group B was concerned that (European) consumers may be concerned about increased productivity, but may welcome improved conditions and welfare for the production animals. In addition, Group A highlighted uncertainty about the significance of the disease in question for the production animals. Group B expected production animals to benefit from being more robust; however, they also raised concerns that more robust animals may lead to reduced welfare because owners may choose less optimal housing conditions. Both groups pointed out the potential impacts for developing countries, but they were also worried that because of the unjust conditions characterizing the international market these potentials may not be realized. 
This is a post-print version of an article published in Science and Engineering Ethics by Springer For more articles on animal ethics, see www.animalethics.net

\begin{tabular}{|c|c|c|c|}
\hline & Respect for & & \\
\hline Interest group & WELLBEING & AUTONOMY & JUSTICE \\
\hline $\begin{array}{l}\text { PRODUCERS } \\
\text { /INDUSTRY }\end{array}$ & $\begin{array}{l}\text { New products for Industry that will be } \\
\text { purchased by the industry - Technlogy } \\
\text { Innovation } \\
\text { Large economic impact for Dairy Producers - } \\
\text { due to reduced production (for this case) ??? }\end{array}$ & $\begin{array}{l}\text { The benefit depends on the nature of the } \\
\text { disease. } \\
\text { This research can give more choice } \\
\text { BUT environmental changes may result in } \\
\text { positive changes. } \\
\text { If only limited number of diseases are study } \\
\text { or only limited number of products tested +/- } \\
\text { BUT this testing can help farmers make } \\
\text { choices about other drugs }\end{array}$ & $\begin{array}{l}\text { Different Producers - Will this research } \\
\text { benefit only industry in Developed Countries. } \\
\text { but not Emerging Econ / Developing } \\
\text { Countries }\end{array}$ \\
\hline $\begin{array}{l}\text { CONSUMERS } \\
\text { /CITIZENS }\end{array}$ & $\begin{array}{l}\text { Protection for consumers - protection from } \\
\text { disease (food safety) } \\
\text { Some consumers concern about the type of } \\
\text { experiements that result in new treatments } \\
\text { for animal disease } \\
\text { Drugs produced from this research can be a } \\
\text { risk to the consumer }\end{array}$ & $\begin{array}{l}\text { Help consumers - in terms of the supply of } \\
\text { milk }\end{array}$ & $\begin{array}{l}\text { Different Consumers - Will this research } \\
\text { benefit only consumers in Developed } \\
\text { Countries. but not Emerging Econ / } \\
\text { Developing Countries }\end{array}$ \\
\hline SCIENTISTS & $\begin{array}{l}\text { For this area - Scientists need to clarify the } \\
\text { difference between 'facts about benefits and } \\
\text { outcomes' and scientist's belief / or view }\end{array}$ & $\begin{array}{l}\text { - Questions about the use of animals may } \\
\text { result to few animals being used - so not }\end{array}$ & $\begin{array}{l}\text { Need to think about alternative ways of } \\
\text { obtain this information. However higher }\end{array}$ \\
\hline
\end{tabular}


This is a post-print version of an article published in Science and Engineering Ethics by Springer For more articles on animal ethics, see www.animalethics.net

\begin{tabular}{|c|c|c|c|}
\hline & $\begin{array}{l}\text { Need to consider } \\
\text { The need to find ways to link fundamental } \\
\text { and applied research. Jobs for fundamental } \\
\text { or clinical research are limited, only some } \\
\text { 'key areas' are funded. This limits jobs and } \\
\text { research quality and interest. Long term } \\
\text { planning is important - the need to have } \\
\text { sustainable programmes and research areas }\end{array}$ & $\begin{array}{l}\text { statistically significant. Scientists work can be } \\
\text { restricted. } \\
\text { - Concern about Professional Freedom - if } \\
\text { the results is only funded by Industry - the } \\
\text { ownership / IPR for the results are owned by } \\
\text { the company. } \\
\text { - Resisted ability to publish if this research } \\
\text { area is funded by industry (Solution - co- } \\
\text { funding industry and government) }\end{array}$ & $\begin{array}{l}\text { efficiency for these studies / positive impacts } \\
\text { can tbe } \\
\text { There may be publication controls from the } \\
\text { industry funder. }\end{array}$ \\
\hline $\begin{array}{l}\text { ANIMALS IN } \\
\text { RESEARCH }\end{array}$ & $\begin{array}{l}\text { - Concern for the suffering of the animal? } \\
\text { - Substitute with other models (do we need } \\
\text { to use these animals to obtain this } \\
\text { knowledge). } \\
\text { - Is this the right type of experiment? } \\
\text { - Use of animal models more important for } \\
\text { some diseases (virus vs bacteria) } \\
\text { - Is in vivo needed - do we need to use this } \\
\text { number } \\
\text { - Slaughter can reduce suffering (if they are } \\
\text { suffering - so death is not a welfare problem) }\end{array}$ & $\begin{array}{l}\text { Animals in these studies have very limted / } \\
\text { NO freedom }\end{array}$ & $\begin{array}{l}\text { Could other species be used? } \\
\text { Consider the outcome of the study for the } \\
\text { animal - i.e. do we need to kill the animal. } \\
\text { We need to justify the impact for the animal. } \\
\text { In X-country 'to kill or not to kill is an issue' }\end{array}$ \\
\hline
\end{tabular}


This is a post-print version of an article published in Science and Engineering Ethics by Springer

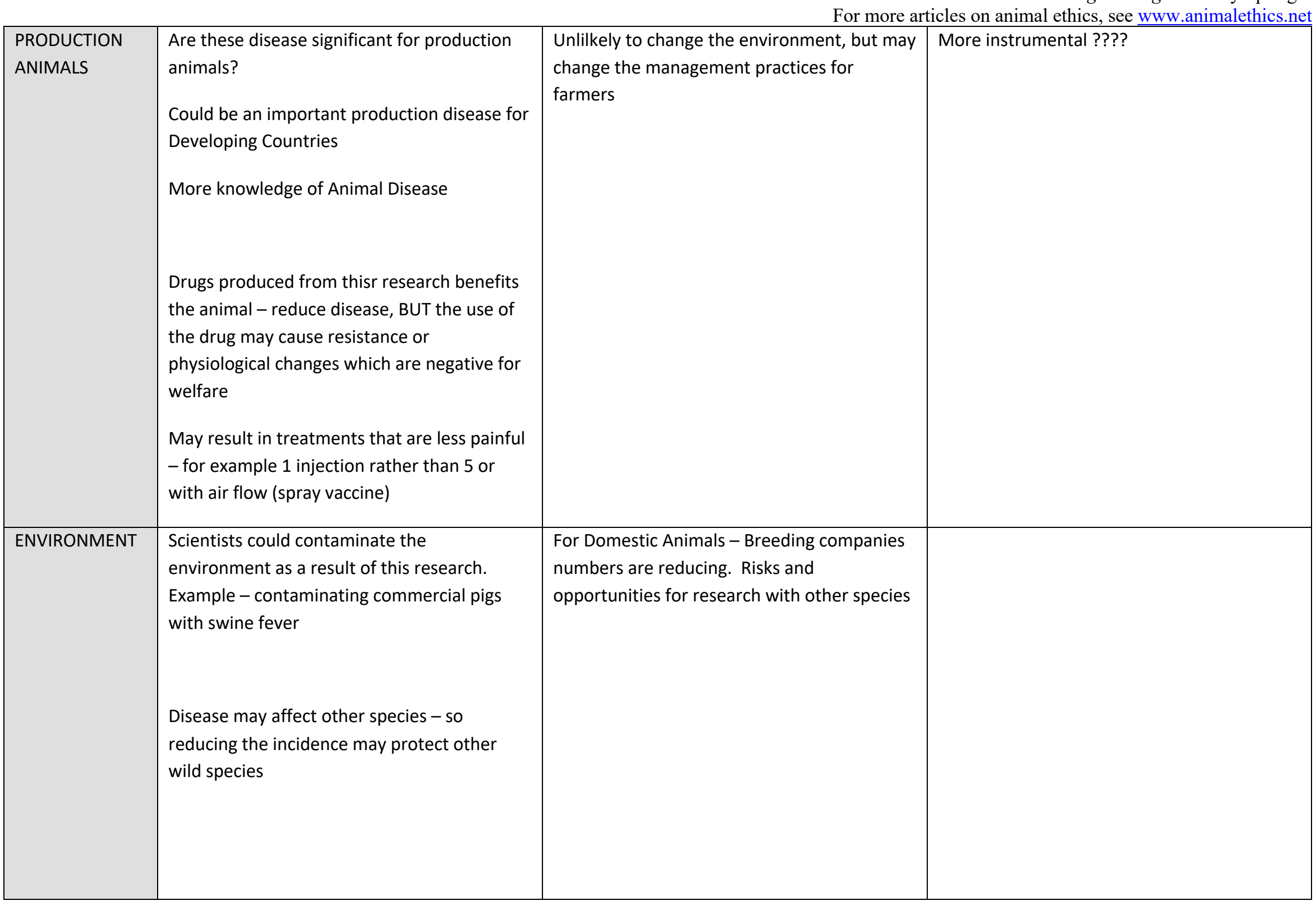


This is a post-print version of an article published in Science and Engineering Ethics by Springer For more articles on animal ethics, see www.animalethics.net

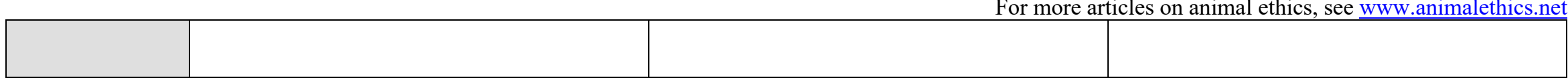

Figure 3: Filled in matrix $A$ 
This is a post-print version of an article published in Science and Engineering Ethics by Springer

\begin{tabular}{|c|c|c|c|}
\hline Interest group & WELLBEING & AUTONOMY & JUSTICE \\
\hline $\begin{array}{l}\text { HEN BREEDING } \\
\text { ORGANISATIONS }\end{array}$ & $\begin{array}{l}\text { Enhances availability of robust and } \\
\text { productive lines for sale also in the future + } \\
\text { Respects professional concern for producing } \\
\text { healthy animals + }\end{array}$ & $\begin{array}{l}\text { Respects their autonomy and } \\
\text { enhances their ability to } \\
\text { compete }+\end{array}$ & $\begin{array}{l}\text { Creates even more inequality between big and small } \\
\text { breeders? } \\
\text { May enhance options for local breeders? } \\
\text { Would this increase competition in disfavour for local } \\
\text { breeders? }\end{array}$ \\
\hline EGG PRODUCING CHAIN & $\begin{array}{l}\text { Robust lines will enhance productivity, } \\
\text { reduce risk and enhance thus income + } \\
\text { Improves labour conditions + }\end{array}$ & $\begin{array}{l}\text { Increases their choice of genetic } \\
\text { lines + } \\
\text { May give them more options } \\
\text { (with regard to housing, etc.) as } \\
\text { these lines are more robust + }\end{array}$ & $\begin{array}{l}\text { It is a general feature of global competition/market: Is } \\
\text { it equally available for all producers? - is the } \\
\text { necessary infrastructure in place? Will it increase the } \\
\text { difference b[et]w[een] rich and poor? }\end{array}$ \\
\hline $\begin{array}{l}\text { CONSUMERS/CITIZENS } \\
\text { (DEVELOPED WORLD) }\end{array}$ & $\begin{array}{l}\text { European consumers: may not like this } \\
\text { increase in productivity, but may like better } \\
\text { iving conditions and improved animal } \\
\text { welfare +/- }\end{array}$ & Having more choice + & No effect 0 \\
\hline $\begin{array}{l}\text { SOCIETAL CONCERNS } \\
\text { (GLOBALLY) } \\
\text { CONSUMERS/CITIZENS }\end{array}$ & $\begin{array}{l}\text { Global consumers: Will help meeting the } \\
\text { demand for animal protein at lower prices. + } \\
\text { More eggs per animals } \rightarrow \text { food security. }+\end{array}$ & \begin{tabular}{|l} 
Make small farmers more \\
dependent on big \\
multinationals? - \\
- but they still have choice of not \\
buying + \\
Having more choice +
\end{tabular} & $\begin{array}{l}\text { In principle robust poultry would help people get out } \\
\text { of poverty better than larger animals }+ \text { ? }\end{array}$ \\
\hline
\end{tabular}


This is a post-print version of an article published in Science and Engineering Ethics by Springer

\begin{tabular}{|c|c|c|c|}
\hline \multicolumn{4}{|c|}{ For more articles on animal ethics, see www.animalethics.net } \\
\hline SCIENTISTS & $\begin{array}{l}\text { Gaining more insight is in the interests of } \\
\text { scientists/advancement of science }+ \\
\text { Working in the interest of the common good }\end{array}$ & $\begin{array}{l}\text { Does not affect academic } \\
\text { freedom directly } 0\end{array}$ & No impact 0 \\
\hline ANIMALS IN RESEARCH & $\begin{array}{l}\text { They suffered by injections, blood samples, } \\
\text { the illness, etc. - }\end{array}$ & No autonomy - & $\begin{array}{l}\text { Is it fair to use one group to the benefit of others? } \\
\text { This group is as small as possible, and there is no } \\
\text { alternative + (?) } \\
\text { The information justifies using the group } \\
\text { More observations could have been done (e.g. } \\
\text { regarding welfare) }\end{array}$ \\
\hline PRODUCTION ANIMALS & $\begin{array}{l}\text { Expected to benefit from being more robust } \\
\text { More robust hens could stay outdoors + } \\
\text { May lead to reduced welfare because owners } \\
\text { may choose less optimal housing conditions - } \\
\text { Environmental challenges as a result of more } \\
\text { iberal conditions may lead to better immune } \\
\text { system + }\end{array}$ & $\begin{array}{l}\text { If this leads to chicken being } \\
\text { more outdoors or free range, it } \\
\text { would give them more natural } \\
\text { behaviour. ??? }\end{array}$ & Will improve life for production animals + \\
\hline ENVIRONMENT & $\begin{array}{l}\text { More robust hens could stay outdoors and } \\
\text { less regulation of temperature: less energy } \\
\text { use? } \\
\text { Less use of antibiotics? }\end{array}$ & $\begin{array}{l}\text { Biodiversity decreases: fewer } \\
\text { hen lines if local breeders are } \\
\text { knocked out by a generalists - ? }\end{array}$ & Not known, depends on many factors. ?? \\
\hline
\end{tabular}


This is a post-print version of an article published in Science and Engineering Ethics by Springer

For more articles on animal ethics, see www.animalethics.net

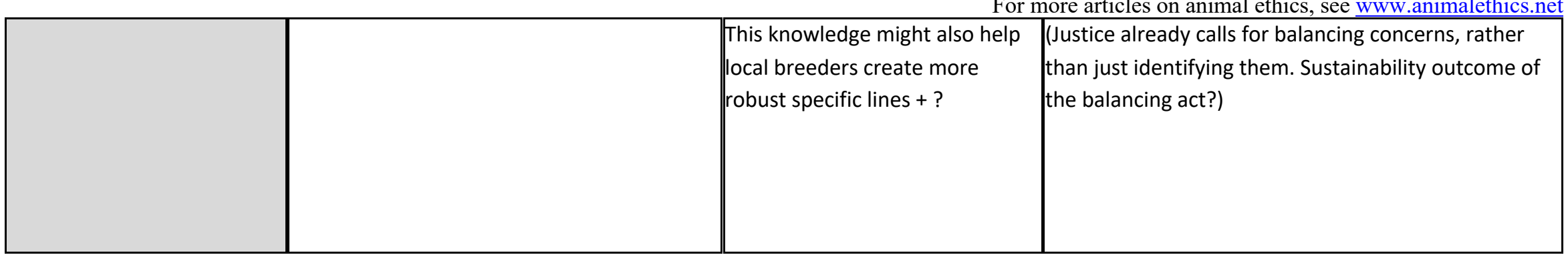

Figure 4a: Filled in Matrix B. 
This is a post-print version of an article published in Science and Engineering Ethics by Springer

For more articles on animal ethics, see www.animalethics.net

Overall benefits such as increased production efficiency for producers (in theory leading to lower prices or more choices for consumers), improved food security for the developing countries, but also better welfare for production animals were more or less identified within the discussion across all workshops. In some cases, increased food safety was also reflected on as an issue. Improved welfare for production animals was identified as an issue for all workshops.

When discussing their own role as stakeholders, group B identified the scientific ambition of gaining fundamental insights, and for many groups this appeared to be a notable point or motivator. Group A indirectly indentified the same issue by linking quality of research and interest in fundamental research; however, the perception amongst the participants was that funding for basic research is rather limited. This concern was similarly raised in many of the groups. Group A also discussed the notion of what scientists believe to be benefits, which may not transpire or be 'true' benefits. This aspect appears to be represented in group B's discussion regarding more robust breeds, which by contrast to initial expectation, may lead to reduced welfare. Similar issues, framed by some as final outcomes of research that can be influenced by factors outside the scientists' control, were raised in other groups. Moreover, notions of academic freedom were discussed in group A in the form of concerns about restrictions on the right to publish (if research involves commercial IPR constraints). These issues were also identified across other workshops alongside aspects of patenting and the issues surrounding private ownership of data. Group B did not have such concerns, however.

When examining the 'costs' of the research in question, these were discussed by both groups and characterized as been significant for research animals, who may 'suffer' during experiments. Both groups identified the aim of reducing the numbers of animals used as small as possible. Both groups also considered whether there were alternatives; Group A explicitly mentioned whether other species could be used, or whether killing an animal is necessary. Similar considerations along the lines of the application of the 3Rs concept (i.e. Replacement, Reduction and Refinement) in animal experimentation took place in other groups. However, when discussing the concept of reduction as it was noted by one group, that if a sample size (number of animals) becomes too small to draw significant conclusions from an experiment, then the benefits of conducting the research may get lost or invalid. Both groups raised the question whether the negative impact on the animals in research could be justified. Group B noted that the suffering must be justified by the production of (gain in) information. Group A raised the questions of whether each experiment in question is the right experiment, and whether the experiment really is needed. In one form or another, this kind of balancing was part of the discussion across all groups.

As can be seen from the example matrices, many other issues were proposed and discussed, e.g. consumer choice, concentration of influence in breeding industry, possible effects on wildlife, biodiversity and many others. However, it is beyond the scope of this paper and not the focus of the data capture to analyze the detailed complexity discourse outcomes. 
This is a post-print version of an article published in Science and Engineering Ethics by Springer For more articles on animal ethics, see www.animalethics.net

\begin{tabular}{|c|c|c|c|}
\hline \multicolumn{4}{|c|}{ For more articles on animal ethics, see www.animalethics.ne } \\
\hline & Respect for & & \\
\hline Interest group & WELLBEING & AUTONOMY & JUSTICE \\
\hline HEN BREEDING ORGANISATIONS & & & 4 \\
\hline EGG PRODUCING CHAIN & & $\begin{array}{l}\text { Access } 4 \\
3 \\
\rightarrow 4\end{array}$ & \\
\hline $\begin{array}{l}\text { CONSUMERS/CITIZENS } \\
\text { (DEVELOPED WORLD) }\end{array}$ & & & \\
\hline $\begin{array}{l}\text { SOCIETAL CONCERNS } \\
\text { (GLOBALLY) } \\
\text { CONSUMERS/CITIZENS }\end{array}$ & $\begin{array}{l}\text { Demand for protein } 25 \\
\text { Food security } 1 \\
\rightarrow 2\end{array}$ & $\begin{array}{l}\text { Small farmers dependence } 3 \\
\text { Self sufficiency and access to food } 2\end{array}$ & \\
\hline SCIENTISTS & More insight 5 & Academic freedom 4 & \\
\hline ANIMALS IN RESEARCH & 1 & & 5 \\
\hline PRODUCTION ANIMALS & $\begin{array}{l}\text { Lead to less optimal conditions } 11 \\
\text { Improvement of robustness } 1\end{array}$ & Larger range of conditions 3 & \\
\hline
\end{tabular}


This is a post-print version of an article published in Science and Engineering Ethics by Springer For more articles on animal ethics, see www.animalethics.net

\begin{tabular}{|l|l|l|l|}
\hline & Expected benefit 2 & & \\
& Better equipped for conditions 1 & & \\
\hline ENVIRONMENT & Less energy use 3 3 & Biodiversity decreases 4222 & 3 \\
\hline
\end{tabular}

Figure 4b: Matrix B: Priorities 
This is a post-print version of an article published in Science and Engineering Ethics by Springer

For more articles on animal ethics, see www.animalethics.net

Figure $4 \mathrm{~b}$ shows the assessment of the significance of the issues in Matrix B indicated by numbers. For this aspect of the discussion a number indicates the significance assigned to the issue by the members of the group (e.g. member(s) of the group regarded significance). The numbers preceded by an arrow show highly prioritized issues as a visual reporting approach used in the matrix (chosen or agreed by the group itself), although this did not represent all other groups' approaches to reporting. However, this figure gives an indication of the variance of opinion with a group. 4 out of 6 agrees on the first priority, but only in terms of the overall issue 'production animals'; within this subject, they put weight on different aspects, and they split on whether they put the weight on the positive aspect of improved conditions or on the risk of less optimal conditions. This reveals that the group was able to agree on a mapping of issues while at the same time containing considerable variation across participant in the assessment of these issues.

A 'filled in' matrix illustrating the discussions within the workshops with wider representation (i.e. beyond scientists) is represented in Figure 5 (prioritized issues are highlighted). The participants, echoing participants' discussions in the four other workshops, identified a number of expected benefits of animal disease genomics research. Future production animals could become more resistant to diseases, and this could improve their welfare. Consumer benefits were also discussed, e.g. in terms of reduced risk of zoonotic infections and availability of cheaper products due to increased efficiency. The impacts on producers, bound to improve efficiency at ever point, and potential to develop more environmental friendly breeds were also discussed.

The costs were mainly considered to impact on the research animals involved in disease challenge testing. Participants put forward their views on the risk of choosing the 'wrong' breeding goals, with increased efficiency potentially leading to a negative impact on the welfare of production animals and consumer concerns about harms. A prominent point was the difference between genomics-based breeding and traditional selective breeding, in that genomics speeds up the selection process which may increase the risk of the 'wrong' choices being quickly embedded throughout the industry to a point when it may be too late to reverse any adverse effects in a cost-effective way. Hence, negative impacts may be forced on consumers.

When discussing the risk of reduced genetic diversity similar concerns were identified in the parallel group, where the concentration of power in the breeding industry and a lack of full transparency regarding the selection of breeding goals in these types of research programme was discussed. As Matrix $\mathrm{C}$ shows, this group further explored the potential negative impact on animal integrity as an issue, whereas the parallel group did not. In terms of the scientists, it was noted that individuals working with animals are concerned about exposing these animals to diseases. 
This is a post-print version of an article published in Science and Engineering Ethics by Springer For more articles on animal ethics, see www.animalethics.net

\begin{tabular}{|c|c|c|c|}
\hline & \multicolumn{3}{|c|}{ Respect for } \\
\hline Interest group & WELLBEING & AUTONOMY & JUSTICE \\
\hline PRODUCERS/INDUSTRY & $\begin{array}{l}\text { NOTE - Producers must improve all of the } \\
\text { time - if all the breeding companies agree } \\
\text { not to use genomics (breeders would be } \\
\text { happy) } \\
\text { - Important tool for breeding companies, } \\
\text { this is innovation that drives the industry. } \\
\text { For clients } \\
\text { Pigs and poultry industry have accepted } \\
\text { this technology, but other sectors have not } \\
\text { (other issues). Some breeders feel } \\
\text { threatened } \\
\text { Big question - is why do we want to breed } \\
\text { this animal? }\end{array}$ & $\begin{array}{l}\text { Technology speeds up the selection process. } \\
\text { could use the 'wrong' technology }\end{array}$ & \\
\hline CONSUMERS/CITIZENS & $\begin{array}{l}\text { Benefits - cheap / less zoonotic infection / } \\
\text { - but it worries consumers - concerned } \\
\text { about 'harm', but this has cost implications }\end{array}$ & $\begin{array}{l}\text { Speeding up genetic progress inhibit the voice } \\
\text { of consumers (-ve) } \\
\text { We don't like technologies been forced } \\
\text { obtain us - we want to see if they 'work' }\end{array}$ & \\
\hline
\end{tabular}


This is a post-print version of an article published in Science and Engineering Ethics by Springer

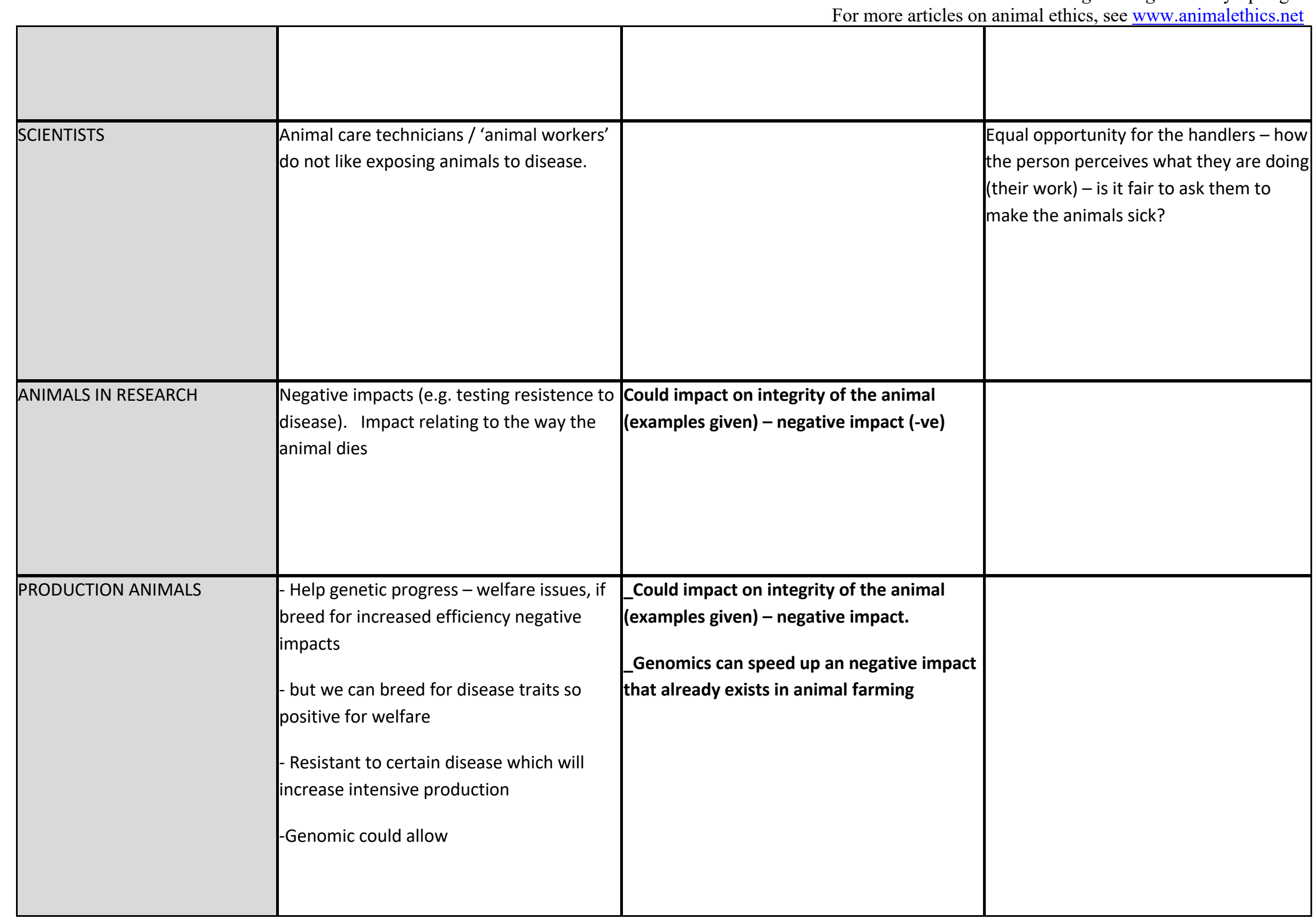


This is a post-print version of an article published in Science and Engineering Ethics by Springer For more articles on animal ethics, see www.animalethics.net

\begin{tabular}{|l|l|l|}
\hline ENVIRONMENT & $\begin{array}{l}\text { Select for traits - nutrient use of cows - } \\
\text { less food and less 'gases' } \\
\text { Feed efficiency }\end{array}$ & $\begin{array}{l}\text { Transforming animals - impair respect for } \\
\text { their inherent value } \\
\text { Any change 'can not be taken out' - can't } \\
\text { take back (-ve) } \\
\text { can capture genetic diversity }\end{array}$ \\
\hline
\end{tabular}

Figure 5: Filled in Matrix C 
This is a post-print version of an article published in Science and Engineering Ethics by Springer

For more articles on animal ethics, see www.animalethics.net

\section{Evaluation of the workshops: content and process}

Before examining the evaluation of the workshops, it is important to refer to some other attempts that were made within the EADGENE network to improve understanding and awareness of ethical issues that are shared by scientists and other citizens; that is to say, issues that are crucial to the relationship between science and society. These attempts (which took place within the first 18 months of the Network's existence) aimed to prepare the ground for the explicit development of norms and practices for deliberation on such issues within the network. The tangible outcome was a proposal on how to proceed, related to three areas of interplay between the network and the public at large: public relations, openness and animal welfare (Meyer et al. 2005a), and a proposal of principles for future practice (Meyer et al. 2005b).

The results from a series of interviews with selected scientists throughout the network indicated that the awareness about the relationship between science and society was somewhat mixed. At the same time, there appeared to be considerable disagreement concerning basic assumptions and values. Practices and routines regarding reflection and discussion on these questions were absent in the network. Thus, a need to initiate discussions of that kind within the network was identified. However, though some interaction and discussion took place, and more in depth interviews were carried out, the Network did not seem to identify with or gain from these activities. The main reason for this failure appears to be that the scientists in the network could not identify themselves within the proposed principles; they seemed to perceive the efforts as some external agenda being more or less forced upon them.

As compared with these efforts, the workshops were characterized as successful as viewed from two perspectives: from a qualitative assessment of the nature of workshop discussions and from the participants' own evaluation. In terms of content, it seems that the scientists were capable of giving voice to the interests of other groups, and in doing so they appeared to be under no obvious interest-based bias. For instance, they were very open and frank in discussions of the impacts of animal research and in the fact that research animals can suffer as a consequence of the research undertaken. Notable concern about the welfare of research animals was expressed over and above the requirement to respect 'the regulations'. Also, the scientists articulated the limits of their own work and critically scrutinized it. There was clear reflection on uncertainties, and also clear references to the wider context in which the research operates. In all cases the discussions thus ended up being conducted at a high level of complexity and depth, and were perceived as meaningful and important by the participating scientists.

However, during the Matrix workshops fundamental value conflicts amongst the participants were not recorded. The main reason for this may be that the specified task for the participants was to map issues collectively through dialogue and not to reach a decision which may have elicited different perspectives or differences of opinion. An exploration of individual fundamental values was therefore not carried out, as was carried out in the one-to-one semi-structured interviews. When the participants answered questions about their own ethical views as expressed in the evaluation form, more variation was visible. Also, Figure $4 \mathrm{~b}$ indicates that the method made room for different value-based perspectives to be expressed.

The participants assessed the workshop using an evaluation form, as well as verbally in the last discussion session of the workshop. This section will focus on the evaluation forms $(74 \%, 35 \%, 92 \%$ and $71 \%$ return rates respectively - we are uncertain as to why one is so low -in total 44 respondents) with some of the key points presented below: 
This is a post-print version of an article published in Science and Engineering Ethics by Springer

For more articles on animal ethics, see www.animalethics.net

- All participants responded positively to the question 'What was your overall impression of the workshop?' Participants included comments such as: 'Interesting', 'Good'. 'Successful in terms of communicating ideas of people with different backgrounds', 'The overall format worked well', 'Thought provoking'

- 42 out of 44 respondents reported that the use of the modified Ethical Matrix aided the process of ethical deliberation, although a number of specific comments should be noted such as 'It helps, but in some extent the matrix seems to restrictive to me - That's why I asked questions about the choice and meaning of the items in rows and columns.' Others commented that 'It gave ideas to start the discussion and to have a wide view of the subject' and 'It made people think hard about the implications of their work'. In a few cases respondents pointed out that some cells were unclear and needed interpretation (e.g. 'justice' in relation to 'the environment').

- $38(\mathrm{n}=44)$ responded positively to the question 'What is your overall view of the EM [Ethical Matrix] method used here?' Some typical responses were: 'Useful - provides a framework for approaching the issue', 'Positive - I got much more out of the short discussion than I have from unfacilitated discussions in similar groups', 'A very simple tool which improved communication greatly', 'Good method but sometimes difficult to use - not all the boxes were that clear' 'Has the benefit to avoid debates about the general stand points'.

In general, it seemed that the participants felt the workshops functioned well. No strong objections to this way of facilitating the discussion of ethical issues (in relation to animal disease genomics) were expressed. Therefore it may be concluded that the outcomes of these workshops have a certain level of credibility for the participating scientists.

It is also interesting to compare the four EADGENE Network internal workshops with the workshop involving external stakeholders. One difference was that in the four internal workshops more time was spent on identifying factual details about genomics and it possible uses which the external stakeholders were possibly less acquainted with. This left less time for discussion of the ethical issues. Looking at the outcome of the discussions, there were some differences. In the external workshop, one group of participants (but not the other) stressed a concern for animal integrity, which was not raised in the internal workshops, and the group as a whole stressed more significantly the negative impacts of increased efficiency as a possible outcome of the research, where increased efficiency in the internal workshops often was seen as a demand from the market. However, the external workshops did not explicitly raise issues regarding developing countries, which was raised in many of the internal groups and concerns about poor quality of research programmes, resulting in unjustified suffering of the animals used for the research was more stressed in the internal workshops.

Thus, there were some differences in perspectives and framing, but the presence of external stakeholders did not appear to make a substantial difference in the complexity or overall substance of the discussions.

However, it is only possible to highlight observations like these from the workshops as the material does not allow strong conclusions to be drawn here.

In the workshop that involved external stakeholders, the participants also filled out a feedback form (75\% return rate) and these results suggested that the evaluation of this workshop was slightly less positive than the feedback from the first four events. Although the overall evaluation of the workshop was clearly positive, a number of critical remarks were made. Several participants answered 'Both' to the question 'Did the use of the Ethical Matrix aid, or hinder the process for this workshop?' process. Some comments were: It did tend 
This is a post-print version of an article published in Science and Engineering Ethics by Springer

For more articles on animal ethics, see www.animalethics.net

to constrain some of the discussion; I thought it encouraged some people to talk, but perhaps not everyone; Useful, but could have been better if more time were allowed; Very useful, but more explanation would have helped and It helped, but I preferred when we used a concrete example (first workshop).

Not surprisingly, it is difficult to pinpoint a single factor for the multi-stakeholder workshop being evaluated slightly less positively than the previous workshops, but the comments from this workshop are informative and highlight individual experience.

\section{Discussion}

Using the two evaluation perspectives (analysis of the discussions and participants' evaluation) it appears that the format stimulated wide ethical reflection among the participating scientists, and that many participants found the modified Ethical Matrix helpful. Two factors may have facilitated the ability of the scientists to address such a broad range of issues as was seen in the four workshops without representation of external stakeholders; the Ethical Matrix as a framework designed to guide a wide exploration of values with facilitators assisting participants to address a wide range of issues. As such, the combination of the Ethical Matrix framework and active facilitation is likely to have impacted on the output. As experience on the counter factual situation where the scientists would reflect on ethical issues without such factors is not examined here, appropriately stronger conclusions cannot be draw. However, these finding seems to suggest that stakeholder involvement in all forms of ethical engagement or reflection processes may not be as vital as previously assumed. The observation that scientists have perceptions that deviate from the general public and express values not necessarily in alignment with the other groups of society does not necessarily imply that they are unable to acknowledge, reflect upon and at times 'give a voice' to other perspectives and valuerelated concerns. Within the limits of the empirical material presented here, it is valuable to examine a number of new possible approaches that may aid the process of facilitating ethical reflection in scientific programmes.

Firstly, there may be reasons to reconsider the active involvement of a wide range of stakeholder groups in some participatory ethical reflection processes. From the perspective of most ethical theories, actual stakeholder representation is in fact not a necessary component for ethical reflection. Ethical reflection evolves if subjects engage in 'putting themselves in the shoes of others' and hence reflect on key issues from the point of view of various affected parties. Hence, from this perspective, stakeholder representation is grounded in heuristic reasons, ensuring that other parties' points of view are made openly known in the reflection process. However, if the participants in the reflection process are able to present values and issues that are important to other parties, stakeholder representation may not appear to be a necessary condition for successful ethical deliberation, although it is widely acknowledged that actual stakeholder representation may of course still be helpful and important for other reasons and in some circumstances can be vital for governance reasons.

Moreover, it is important to note that for some cases there may be a risk that the inclusion of diverse groups of stakeholders will hinder or 'shut down' ethical reflection. As observed in this case, it may be important to hold discussions within a homogenous group of scientists. This may have made the scientists feel more confident and comfortable when discussing ethical dimensions and addressing complex issues relating to their work. This again seems to be an important element that may allow scientists' to 'open up' when discussing other perspectives as well as making room for internal critique. Being directly confronted other stakeholder representatives or perceiving that the workshop facilitation team has an agenda both represent a 
This is a post-print version of an article published in Science and Engineering Ethics by Springer

For more articles on animal ethics, see www.animalethics.net

participation risk for scientists. In these circumstances they may feel themselves 'under attack' and, as a counter-productive consequence, may take up a defensive attitude and close ranks rather than engaging openly in reflection. This suggests that in some cases feeling 'confident and comfortable' amongst likeminded individuals, particularly for scientists who are able to represent other parties, may be more productive for ethical reflection than directly involving other stakeholders. Thus there is a risk that scientists will not feel 'confident and comfortable' and consequently react defensively, were other stakeholders to be directly involved.

The significance of this observation also comes from comparing the feedback to the other prior attempts within the EADGENE Network to initiate and report ethical reflection among the scientists. The main critique of this attempt was that the scientists themselves did not feel accurately represented. The evaluation forms suggest that the scientists, when using the matrix, largely did not feel that there were any hidden agendas or that they were pressed to follow an external agenda.

On the other hand the observation, with caveats, that the workshop with external stakeholder also worked well may challenge the above highlighting that broad and open discuss can take place. In this case at least, there was no serious reason to believe that the presence of external perspectives made the scientists less willingly to engage in dialogue. However, the actual setting and format may be important. In this case, the scientists appeared to be confident and open to external dialogue, and this confidence may have resulted from their involvement in previous matrix workshops.

Moreover, it should be acknowledged that the local workshops were not closed to the genomic research community, since EADGENE partners from the breeding industry also participated. This involvement may have represented a perspective, which was external to the scientific community and at the same time these project partners, specifically the industry partners, share the scientific training and a common link to the research work. Also, in most workshops at least one participant, who was also involved or linked to the EADGENE project, had a professional ethics background, and that may have represented a stimulating additional perspective.

If the value of directly engaging with external stakeholders is not necessary for heuristic reasons, but may have negative impact on confidence and the ability of scientists to broad reflection, then an argument might be made in favor of developing process that does not require external input.

However, from a governance and social accountability perspective the dialogue and interaction between scientists and the public and other stakeholders remains crucially important. It is not helpful if scientists show capacity to engage in broad ethical reflection about their research programmes, if this reflection process and the increased capacity does not translate into better interaction and dialogue regarding research priorities and policies with external stakeholders and the wider public. Therefore, after scientists have had the opportunity to first reflect openly and critically among themselves, they should go beyond the traditional scientific community and interact with and be challenged by the 'external' community in an open valuebased dialogue.

\section{Conclusion}

The main question raised in this paper was the degree to which it is possible to have valuable ethical reflection without actual representation of affected parties/stakeholders if a method, such as the ethical 
This is a post-print version of an article published in Science and Engineering Ethics by Springer

For more articles on animal ethics, see www.animalethics.net

matrix, stimulates reflection beyond traditional value boundaries of the group. The outcome of the workshops indicates that value discussion can occur even when participation is restricted to a single group of experts. One reason for involving external stakeholders in an ethical reflection process is to ensure that the viewpoints of other parties enter the process. However, involvement purely for this reason is not always necessary, and some parties, e.g. animals or the environment, must always have anyway their views represented. In some cases the desire to ensure that participants feel confident enough to engage openly in dialogue may even refute the involvement of external stakeholders.

Other reasons for involving external stakeholders remain important if the ethical reflection is intended to yield a final judgment or conclusion that has consequences for different stakeholders or for reasons of good governance and social acceptability. In this case issues of democratic legitimacy supporting any recommendation or decision need to be considered. The opportunity for specific stakeholders to voice their opinions directly is part of any democratic decision-making process. Moreover, there is an overarching need for a value-based debate about science and technology developments, involving scientists, other stakeholders and the public.

However, when finally considering some of the wider implications of this work, if the findings reported here are transferable, it seems that for some circumstances an alternative method for engaging with scientists at an early stage of the research process is emerging. As an alternative to involving external stakeholders, it may be possible to run a facilitated ethical reflection process among linked groups of scientists with educational and capacity building purposes. A process of this kind has the advantage of being simple to structure and cost effective. Scientists may initially not be motivated to participate in such processes, but the experience reported here is that the participants themselves did find the exercise worthwhile. Clearly, further questions arise if ethical reflection is required to be 'institutionalized' in some sense and its effects be documented; they go beyond the scope of this present investigation.

\section{Acknowledgements}

We are grateful to the European Union for funding the research underlying this paper through the EADGENE Network (EU Contract No. FOOD-CT-2004-506416, www.eadgene,info).

\section{References}

Kaiser, M. (2005). Assessing ethics and animal welfare in animal biotechnology for farm production. OiE Review. Rev. sci. tech. Off. int. Epiz., 24, 75-87.

England, G. and Millar, K. (2008) The ethics and role of AI with fresh and frozen semen in dogs. Reproduction in Domestic Animals, 43:2:165-171

Forsberg, E.-M. (2007a). A Deliberative Ethical Matrix Method - Justification of Moral Advice on Genetic Engineering in Food Production. Dr. Art. Dissertation. Oslo, Unipub.

Forsberg, E.-M. (2007b). Report from a Value Workshop on GM Rapeseed. In W. Zollitsch, C. Winkler, S. Waiblinger \& A. Haslberger (Eds.), Sustainable food production and ethics (pp. 442-49). Wageningen Academic Publishers 
This is a post-print version of an article published in Science and Engineering Ethics by Springer For more articles on animal ethics, see www.animalethics.net

Jonsen, A.R. \& Toulmin, S. (1988). The Abuse of Casuistry. University of California Press.

Lassen, J., Madsen, K.H. \& Sandoe, P. (2002). Ethics and genetic engineering - lessons to be learned from GM foods. Bioprocess and Biosystems Engineering, 24(5), 263-271.

Mepham, B. (2000). A framework for the ethical analysis of novel foods: The ethical matrix. Journal of Agricultural and Environmental Ethics 12, 165-76.

Mepham, B., Kaiser, M., Thorstensen, E., Tomkins, S. \& Millar, K. (2006). Ethical Matrix Manual. The Hague: LEI.

Millar K and Mepham B 2001. Bioethical Analysis of Biotechnologies: Lessons from Automatic Milking Systems (AMS) and Bovine Somatotrophin (bST). In Occasional Publication Number 28 (eds CM Wathes, AR Frost, F Gordon and JD Wood), pp. 29-36. British Society of Animal Science, Edinburgh.

Meyer G, Gamborg C and Sandøe P 2005a. A Study of Ethical and Societal Issues. Copenhagen, Danish Centre for Bioethics and Risk Assessment.

Meyer G, Gamborg C and Sandøe P 2005b. Ethical Deliberation: Principles. Copenhagen, Danish Centre for Bioethics and Risk Assessment.

Slovic, P. ( 2000). The Perception of Risk. London, Earthscan.

Wynne, B. (1996). May the Sheep Safely Graze? In S.M. Lash, M.B. Szerszynski \& B. Wynne (Eds.), Risk, Environment and Modernity (pp. 44-83), London, Sage. 